\title{
About the Use of Tag Questions in Andean Spanish
}

\author{
Geraldine Quartararo \\ Pontificia Universidad Católica de Chile, Chile \\ E-mail: geraldinequartararo@gmail.com
}

Received: May 5, 2021

Accepted: May 27, 2021

Published: June 9, 2021

doi:10.5296/ij1.v13i3.18601

URL: https://doi.org/10.5296/ijl.v13i3.18601

\begin{abstract}
This paper aims to describe the use of tag questions in the variety of Andean Spanish spoken in Bolivia. In particular, it explores the tag questions that occur in the Corpus oral del español hablado por bilingües de aymara-español. The analysis consists of two levels. On the one hand, it describes the pragmatic functions of tag questions and identifies the correlation between their distribution and their pragmatic functions. On the other hand, it focuses on the impact that social factors (the speakers' sex, age, and education) have on the frequency of the tags. Along these lines, it displays the lack of a general sociolinguistic trend in the use of tag questions, furthermore, it shows that the higher frequency of tags in a sociolinguistic group rather than in another is tag-dependent.
\end{abstract}

Keywords: Tag questions, Spanish, Pragmatic functions, Sociolinguistic analysis

\section{Introduction}

The present paper is structured as follows: Introduction outlines the scope of the paper, the relevant related literature ( $\$ 1.1)$, and finally, the main features of Andean and Bolivian Spanish (§1.2). Section 2 is dedicated to the discussion of the Method. This section is split into two subsections. Section 2.1 describes the characteristics of the corpus and participants. In Subsection 2.2, I outline the method of the data analysis. Section 3 is devoted to the presentation of the qualitative (\$3.1) and the sociolinguistic results (\$3.2). Finally, in Section 4 I discuss the results on the analysis and in Section 5 I draw some final remarks and suggestions for future research.

\subsection{The State-of-the-Art}

Although an extensive number of studies have been devoted to the investigation of tag questions in Peninsular Spanish, (Fuentes Rodríguez, 1990a, 1990b, 2014; Blas Arroyo, 1995; Martín Zorraquino, 1998a, 1998b; García Vizcaíno, 2005, Montañez Mesas, 2008; Brenes 
Peña 2011; Molina Martos, 2016), research on the functioning of these discursive units in American Spanish varieties has received fragmented attention. Only a few varieties have been investigated in any detail, i.e., Argentinian Spanish (Boretti, 1999) Chilean Spanish (Urzúa Carmona, 2006; San Martín, 2011; Gille, 2013, 2015) Ecuadorian Spanish (Fuentes Rodríguez, Placencia \& Palma-Fahei, 2019) and Mexican Spanish (Orozco, 2014). While the investigation of the other varieties is non-existent. Andean Spanish, in general, and Bolivian Spanish, in particular, belong to this second group. By considering this existing knowledge gap, this study aims to investigate the use and functioning of tag questions in the variety of Andean Spanish spoken in Bolivia. In this regard, it is the first descriptive approach to this topic.

The specialized investigations on tag questions in Spanish call these discursive units in several ways: apéndices modalizadores 'modalizing question' (Ortega Olivares, 1985), apéndices apelativos 'appellative questions' (Beinahuer, 1978; Fuentes Rodríguez, 1990a) or apéndices confirmativos 'confirmation questions' (Quilis, 1993). Ortega Olivares (1986) defines Spanish tag questions as,

signos de cuerpo fónico reducido, emitidos siempre con entonación ascendente o ascendente-descendente, y que presentan la peculiaridad común de presentarse asociados a enunciados-base considerados típicos y de hacerlo normalmente al final de estos. (Note 1) (Ortega Olivares, 1986, 272)

The scholar focuses on the influence of tag questions on modality. On this basis, he establishes two functional groups: comprobativos 'supporting tag questions' and justificativos 'justifying tag questions'. The former are used to prompt the receiver to answer, the latter clarify the propositional content of the host sentence by linking it to some type of evidence (Ortega Olivares, 1986, 279).

Further research has observed that the functioning of tag questions is linked to macro-syntactic factors. Along these lines, Briz Gómez (2001) points out the correlation between the distribution of tag questions within the sentence/turn of speaking and their pragmatic functions. When tag questions occur in the final sentence position, they perform the appeal function, that is, the sender expects a direct response from the interlocutor. By contrast, when they occur in the medial position, they usually have the phatic function, that is, the sender does not request the interlocutor's answer, but rather s/he is using the tag to keep open the channel of communication. Against this proposal, researchers (Cortés Rodríguez \& Camacho Adarve, 2005; Padilla García, 2005; Montáñez Mesas, 2007; Briz Gómez \& Estellés Arguedas 2010) have investigated the implications related to the distribution of tag questions within sentence/turn of speaking and their functioning. Four main positions have been detected: the final or right-sentence margin (1), the medial position (2), the initial or left-sentence margin (3), and the isolated position (4).

(1)

1D1: \#Yeti /// yo no soy un criado tuyo ¿eh?\#

1C1: \#no\# / \#eres una sirvienta\# (Gómez Briz \& Grupo Val.Es.Co., 2002, 63, 1. 504)

'Yeti, I am not your servant, ¿eh?' 


\section{$\Lambda$ Macrothink}

'No, you are a servant'

(2)

1D1: \#pero habas de esas dee - no son de las otras / de las congeladas ¿eh? / son de laas que se quita\#

B1: (RISAS) (Gómez Briz \& Grupo Val.Es.Co., 2002, 61, 1. 424)

'But fava beans of those - they are not of those / of the frozen ones ¿eh? they are those that you pick'

'(LAUGH)'

(3)

1L1: \# ¿y qué horas son?\#

1A1: \# ¿eeh?\# / \#de nueve y media aa - a las doce y media\# /// \#oo las diez // hasta la una // o las once hasta las dos\# // \#que hora de entrada tampocoo / tienen / ¿quieres que- [la quieres?]\# (Gómez Briz \& Grupo Val.Es.Co., 2002, 145, 1. 87)

'What time is it?'

'Eeh? From nine-thirty to - to twelve-thirty, or from ten to one, or from eleven to two. They don't even have an entry time. Do you want to ... do you want it?'

(4)

1A1: (RISAS) \#; qué le habéih hecho?\#

1J1: \#; eh?\#

2A2: \# ¿qué le habéih hecho / al Ignacio?\# (Gómez Briz \& Grupo Val.Es.Co., 2002: 161, 1. 754)

'What have you done to him?'

'¿Eh?'

'What have you done to Ignacio'

Montáñez Mesas (2007) establishes three main correlations: at the end of the sentence/turn, tag questions request the receiver's answer; at the end of the act (the medial position of intervention), they reaffirm what was said; and finally, in isolated sentences, they signal a reaction to what was said and serve as a request of clarification.

Fuentes Rodríguez \& Brenes Peña (2014) provides a further contribution to the field. The two scholars demonstrate the polyfunctionality of tag questions by relating their pragmatic functions to the four discursive planes (interactive, modalizing, informative, and enunciative). Thus, the scholars distinguish seven main functions:

- The phatic function, the tag question is used to ensure the reception of the message (interactive plane).

- The appeal function, the tag question is used to seek the interlocutor's answer (interactive plane).

- The reaffirming function, the tag question is used to reaffirm the sender's opinion (modalizing plane). 
- The modal function, the tag question supports another modal by mitigating or reinforcing it (modalizing plane).

- The informative function, the tag question simultaneously emphasizes the known information and introduces the new one (informative plane).

- The focus function, the tag question emphasizes a discursive sequence (informational plane).

- Finally, the repair function, the tag question supports a correction or a reformulation (enunciative plane).

The aforementioned functions are not mutually exclusive (Fuentes and Brenes, 2014, 190), rather they interact with each other within the same tag. It follows that the specific value of a tag results from the configuration of the overlapping of the pragmatic functions in a particular discursive context.

\subsection{Andean and Bolivian Spanish}

In this section, I will point out the main features of the Spanish variety transcribed in the Corpus oral del español hablado por bilingües de aymara-español (Quartararo, forth).

The definition 'Andean Spanish' identifies two different sociolinguistic varieties of Spanish, that is, the L2-Spanish spoken by natives of Andean indigenous languages and L1-Andean Spanish spoken by monolinguals of the same variety (Coronel Molina \& Rodríguez-Mondoñedo, 2012, 450). This paper shows data belonging to the former variety, i.e., the L2-Spanish spoken by natives of Andean indigenous languages. The specialized literature (Pyle, 1981; Mendoza, 1991; Adelaar \& Muysken, 2004; Clancy Clements, 2009; Escobar, 2011; Callisaya Apaza, 2012) unanimously attributes to this variety the following features:

- The phonological alternation between close-mid vowels [e, o] and high-close vowels [i, u] in both stressed and unstressed syllables.

- The extensive use of diminutives with the politeness function.

- The omission of articles, the lack of agreement between gender and number, the lack of number agreement between subject and verb inflection, the redundant possessive, and finally, the use of the preposition "in" with locative adverbs.

- And the final position of verbs in pragmatically unmarked sentences.

Furthermore, given the participants' geographical area of origin, I believe that it is appropriate to also point out the specific features of Bolivian Spanish (Callisaya Apaza, 2012; Laprade, 1981; Mendoza, 1991). The main features of such a variety are reported below:

- The use of andá instead of ve for expressing the second person of the imperative of the verb ir 'go'.

- The use of más antes instead of antes.

- The semantic extension of the adverb siempre 'always' used with emphatic value. 
- The use of the interjection $p s$ with emphatic value.

- The addition of the participative pronoun, such as volví a vivirme 'I came back to life'.

- Finally, the construction "estar de + noun" instead of "tengo + noun", estar de pena instead of tengo pena 'I am sad'.

\section{Method}

\subsection{Data and the Participants' Characteristics}

The data was elicited through the Family Problems Picture task (San Roque et al., 2012) and was collected mainly in La Paz and El Alto (Bolivia). The main objective of the task is to stimulate the oral description of images and the construction of a story with them. The oral and interactive nature of the task encourages typical strategies of the dialogic exchange, such as tag questions.

Thirty Spanish-Aymara bilingual speakers participated in the study (18 males, age range: 18-64). (Note 2) The participant's L2 proficiency in Spanish varies depending on age and education level. The advanced age is related to a lower educational level and also to a greater presence of the typical features of Andean Spanish (cf. §1.2).

Three people participated to each recording session, for a total of ten groups. The participants are acquaintances who, among them, maintain neighborhood, family or study relationships. This last element made it possible to establish symmetrical relationships during the development of the task and, in addition, to guarantee the maintenance of a good level of spontaneity.

The corpus consists of fully transcribed recordings lasting 7 hours and 33 minutes. The transcription rules (Briz \& Grupo Val.Es.Co., 2000) employed have been widely used for transcribing colloquial Spanish since they allow for a faithful representation of oral speech (immediate turn-taking and overlaps, among others). The transcripts show the typical phenomena of both Andean and Bolivian Spanish (cf. §1.2) and also the linguistic imperfections (phonical, morphosyntactic and lexical) as they were pronounced by participants.

\subsection{Analysis Methodology}

The qualitative analysis was developed from the pragmatic functions established by Fuentes Rodríguez \& Brenes Peña (2014). However, given the actual uses of the analyzed tags, it was necessary to extend the original set of functions (cf. §1.1). A new pragmatic function, named 'agreement', has been introduced. Tag questions with this function signal the agreement of the sender with the receiver and, for this reason, were considered to belong to the interactive plane. Thus, the pragmatic functions detected in the corpus are appeal, phatic, agreement, reaffirming, modal, repair, informative, and focus.

Concerning the distribution of tag questions within the sentence/turn of speaking, I took into consideration the four positions already established in the literature (cf. §1.1), that is, the final position, the medial position, the initial position, and the isolated position. 


\section{Mll Macrothink}

International Journal of Linguistics

ISSN 1948-5425

2021, Vol. 13, No. 3

Finally, for the sociolinguistic analysis, participants were distinguished by gender, education level, and age. Regarding the participants' age, 17 people belong to the group 'youths' (age range 18-30), 8 people to the group 'adults' (age range 31-50) and 5 people to the group 'elderly people' (age range > 51). Concerning education, 19 participants have university level, 8 have secondary education and 3 have primary education. The sociolinguistic analysis relates the occurrences of tag questions to the established sociolinguistic groups. The results are presented in relation to two parameters: frequency and percentage. Frequency indicates the tag questions produced by the participants in both absolute terms, i.e., the absolute number of occurrences of tag questions, and relative terms. Relative frequency displays the ratio between the absolute frequency of tags in a specific sociolinguistic group and the total number of observations made. It is always shown as a percentage. Moreover, given the unequal number of participants in each sociolinguistic group, I calculated the ratio between the absolute frequency of tag questions in each sociolinguistic group and the total of words expressed by the same group. This last calculation has guaranteed the comparison of the results for all the sociolinguistic groups.

\section{Results}

Data features 498 tokens of tag questions. Participants used six tags: ¿no?, ¿no ve?, ¿mira?, ¿verdad?, ¿ya? and ¿entiendes?. According to my knowledge, research has devoted much attention to the tags ¿no?, ¿verdad? and ¿entiendes?; limited attention to ¿mira? and ¿ya?; and, almost no attention to the functioning of the tag ino ve?

In the corpus, ¿no? is the most frequent tag with 222 occurrences, whereas ¿entiendes? is the less frequent with only one occurrence. To better appreciate the frequencies of the tags in the data, see Table 1:

Table 1. Distribution of tag questions in the data

\begin{tabular}{lll}
\hline Tag Question & Absolute frequency & Relative frequency $(\%)$ \\
\hline ¿No? & 222 & 44.6 \\
\hline ¿No ve? & 199 & 40.0 \\
\hline ¿Mira? & 54 & 10.8 \\
\hline ¿Verdad? & 17 & 3.4 \\
\hline ¿Ya? & 5 & 1.0 \\
\hline ¿Entiendes? & 1 & 0.2 \\
\hline Total & 498 & 100 \\
\hline
\end{tabular}

\subsection{Data Analysis}

\section{1 .1 ¿No?}

The data shows two tag questions, ¿no? and ¿o no?, in complementary distribution. Except for the formal and quantitative differences, the analysis has not revealed further divergences between these two tags (see examples 5 and 6). The corpus features 25 tokens of ¿o no? and 197 of $¿ n o ?$. In the remainder, I will consider these two tags as free variables of the tag ¿no? 


\section{Macrothink}

(5)

158. P1: después / se ha ido a su casa ¿o no?

159. P2: aquí sí / se ha ido a su casa / ha llegado [...] (6_BL_BOLIVIA)

'After / he went home ¿o no?'

'Yes here, he went home, he arrived'

(6)

92. P1: [...] está - está llorando ps ¿no?

93. P2: sí / está llorando / arrepentido debe estar (6_BL_BOLIVIA)

'He is - is crying ¿no?'

'Yes / he is crying / he must be sorry'

The tag ino? occurs in the initial, medial and final positions. According to the analysis, the tag performs six pragmatic functions (appeal, agreement, phatic, reaffirming, modal and informative).

In the final position, ¿no? mostly displays the appeal function, in other words, the sender uses it to expressly request the receiver's answer. In example (7), ¿no? functions as a pure appellative marker. Whereas, in (8) and (9) the appeal function of the tag interacts with other two pragmatic functions, the modal and the reaffirming ones, respectively.

(7)

61. P1: las tres es lo que participamos / ¿no?

62. ENT: no / ella no participa [...] (2_BL_BOLIVIA)

'The three of us are going to participate ¿no?'

'No, she does not participate'

120. P1: le damos ¿no?

121. P2: sí(5_BL_BOLIVIA)

'Let's start ¿no?'

'Yes'

(9)

44. P1: seguro es un viernes / ¿no?

45. P2: tal vez es un viernes [..] (5_BL_BOLIVIA)

'It is surely a Friday ¿no?

'Maybe it is a Friday'

In (7), the use of the tag is due to the sender's need to confirm the correct understanding of the instructions. In (8), the tag ¿no? is used after an exhortation. It attenuates the illocutionary force of the host sentence and, also, seeks to involve the receiver in the development of the task. Finally, in (9) the sender uses ¿no? to reinforce and, therefore, to reaffirm his interpretation of the image described. 


\section{Macrothink}

International Journal of Linguistics

ISSN 1948-5425

2021, Vol. 13, No. 3

In a small number of cases ( 2 out of 222), the tag ino? occurs in the initial position. It indicates the sender's agreement with something previously mentioned by the receiver. In example (10), for instance, the use of the tag furtherly manifests the sender's agreement towards the information provided by the interlocutor. Such an agreement has been already expressed by the adverb si 'yes'.

121. P2: aquí parece quee están entre TRES / pero aquí está un poco más grande su hijo / ¿o no? I o ¿cómo lo ves?

122. $\mathrm{P} 1$ : síl ¿no? es más grande ya [...] (6_BL_BOLIVIA)

'Here it looks like there are three people, but here his son is a little older ¿o no? How do you see it?'

'Yes ¿no? he is older'

When ¿no? occurs in the medial position, it can have either the agreement or phatic function. In the cases of the agreement function (example 11), the use of the tag follows a precise pattern. It occurs after the information known, with which the sender agrees, and gives way to the new information. (Note 3) When the sender uses ino? according to its phatic function, the tag can work either as a pure phatic marker (12), it is used to keep the listener's attention, or it jointly conveys both the phatic and reaffirming function (13). In these last two cases, ¿no? is a means of encouraging the receiver to share the sender's interpretation.

20. P1: sí / pero está en una - en una cárcel

21. P2: en una cárcel / ¿no? / sí / sí de que es cárcel / es cárcel / o al menos es el arresto / una comisaría (5_BL_BOLIVIA)

'Yes, but he is in jail'

'In a jail ¿no? yes, yes that is jail, it is jail, or at least he is under arrest, a police station'

127. P3: ee bien // dice ¿no? un día había habido / una pareja / que habían vivido / en un valle / (10_BL_BOLIVIA)

'Well, he said ¿no? one day there was a couple who lived in a valley'

254. P2: y acá // empiezan a trabajar / debe ser al día siguiente o más tarde ¿no? (2') ambos trabajan / recogen sus zapallos (3_BL_BOLIVIA)

'And here, they start to work, it must be the next day or later ¿no? they are both working, they are picking their pumpkins'

This section has presented the pragmatic functions of $¿$ no? and their respective examples. Table 2 shows the distribution of the functions of the tag in relation to its position within the sentence/turn. 
Table 2. The pragmatic functions of ¿no?

\begin{tabular}{|c|c|c|c|c|c|}
\hline & PositI & & & & \\
\hline FUNCTION & Initial & Medial & Final & Isolated & TOTAL \\
\hline Agreement-Informative & & 8 & & & 8 \\
\hline Agreement-Focus & 2 & & & & 2 \\
\hline Phatic & & 74 & & & 74 \\
\hline Phatic-Reaffirming & & 49 & & & 49 \\
\hline Appeal-Reaffirming & & & 82 & & 82 \\
\hline Appeal-Modal & & & 3 & & 3 \\
\hline Appeal & & & 4 & & 4 \\
\hline TOTAL & 2 & 131 & 89 & & 222 \\
\hline
\end{tabular}

\subsection{2 ¿No ve?}

In the data, ¿no ve? occurs in all four positions indicated in the literature (cf. §1.1) and performs all functions considered for the present analysis. However, only five functions (appeal, agreement, phatic, reaffirming, and focus) show a significant number of cases.

In the final position ¿no ve? mostly performs the appeal-reaffirming function, that is, the sender uses it not only to request the receiver's confirmation/rejection on what he has understood, interpreted, or given an opinion, but also to reinforce his/her stance toward the information provided (examples 13 and 14). In only one case (example 15), ¿no ve? functions as an appeal-modal marker. Here, the tag is used to attenuate the illocutionary force of the exhortation perceived by the receiver.

90. P1: [...] aquí están compartiendo / ¿no ve?

91. P2: sí / compartiendo (2_BL_BOLIVIA)

'Here, they are sharing ¿no ve?'

'Yes, sharing'

183. P2: esto sería al final casi / ¿no ve?

184. P1: no pero esto no (5_BL_BOLIVIA)

'This would be almost at the end ¿no ve?'

'No, but not this'

184. P2: [...] ¿dónde empieza hora la historia? / ¡a ver!

185. P1: vamos a armar / ¿no ve? (3_BL_BOLIVIA)

'Where does the story begin? Let's see!'

'Let's build / ¿no ve?'

When ¿no ve? occurs in the initial and isolated positions, its functions partially coincide. In both positions, the tag indicates the sender's agreement with something previously mentioned 


\section{Macrothink}

International Journal of Linguistics

ISSN 1948-5425

2021, Vol. 13, No. 3

by the receiver. The difference between the two positions ties to the informative plane. In the isolated position, the tag lost its interrogative value and can be paraphrased with 'that's it' (17). In the initial position, the tag adds further emphasis to the sender's declaration of agreement (16).

212. P2: [...] su familiares debe ser

213. P1: sí ¿no ve? su familiar [...] (2_BL_BOLIVIA)

'His relatives must be'

'Yes ¿no ve? his relative'

146. P2: [...] él quiere escapar entonces esto quiere agarrarle / esto

147. P1: ¿no ve?

148. P2: eso es [...] (8_BL_BOLIVIA)

'He wants to escape, for this reason, this wants to catch him / this'

¿No ve?'

'That's right'

In these two positions, the tag may also convey other functions. In examples (18) and (19), ¿no ve? is used to reaffirming the speaker's interpretation of the images. The difference between the two examples is strictly related to the position of the tag within the sentence/turn.

63. P2: esta debe ser la entrada de la feria

64. P1: podría ser / sí / por aquí hay

65. P2: ¿no ve? están llegando (3_BL_BOLIVIA)

'This must be the entrance of the fair'

'Maybe, yes, there is something around here'

‘No ve? they are coming'

111. P2: [...] este es una prisión // yo veo

112. P1: mm /// ya lo que - esto parece que / a a sí

113. P2: ¿no ve?

114. P1: sí / ya (10_BL_BOLIVIA)

'This is a prison, I see'

'Mm, this looks like, oh yes

¿No ve?'

'Yes'

Unlike the isolated position (18), where ¿no ve? expressly requests the receiver's answer (appeal function). In initial position (19), it works as a phatic marker. In (18), this phatic function is linked to the sender's willingness to take up the information left off in her last turn 


\section{Macrothink}

International Journal of Linguistics

ISSN 1948-5425

2021, Vol. 13, No. 3

(line 63). In (19), the isolated position allows the speaker to use the tag with its interrogative value and to reaffirm the opinion already expressed in line 111.

In the other cases, ¿no ve? occurs in the medial position. In a small number of cases, as ¿no?, the tag displays the agreement-informative function and follows a precise pattern of use, it occurs after the information known and gives way to the rheme. In the remaining cases of the medial position, ino ve? has the phatic function, by using it the sender tries to keep the listener's attention and, simultaneously, structure his/her utterance.

45. P1: [...] como si estuviera pidiendo socorro o ayuda (2') ¿no ve? O ESTUVIERA ARREPENTIDO [...] (6_BL_BOLIVIA)

'As if he were asking for assistance or help ¿no ve? or if he were repentant'

56. P1: ${ }^{\circ}(\text { esto })^{\circ}\left(45^{\prime \prime}\right)$ esto es una pamelia ps / es una pamelia ¿no ve? / ahora / sí / una pamelia

57. P2: ya me he rendido yo [...] (7_BL_BOLIVIA)

'This is a family, it is a family ¿no ve? now, yes, a family'

'I have already given up'

265. P1: [...] aquí ya / con sus amigos / aa ya está yendo con su hijo // ¿no ve? está yendo con su hijo / y él - de - digamos que son sus amigos (3_BL_BOLIVIA)

'Here, with his friends, he is already going with his son ¿no ve? he is going with his son and he... let's say they are his friends'

In (20), in addition to the phatic function, ¿no ve? performs the repair function, it rephrases the preceding words through the words that come after. In (21), the use of $i n o v e$ ? reinforces the sender's interpretation that is furtherly emphasized by the three repetitions of the phrase una pamelia 'a family'. Finally, in (22) ¿no ve? operates as a focus marker, it stresses the information that the speaker considers relevant.

Table 3 shows the absolute frequency of the functions of ino ve? previously discussed in relation to its position within the sentence/turn.

Table 3. Pragmatic functions of ¿no ve?

\begin{tabular}{|c|c|c|c|c|c|}
\hline & POSITI & & & & \\
\hline FUNCTION & Initial & Medial & Final & Isolated & TOTAL \\
\hline Agreement & & & & 6 & 6 \\
\hline Agreement-Focus & 10 & & & & 10 \\
\hline Agreement-Informative & & 10 & & & 10 \\
\hline Phatic-Focus & & 16 & & & 16 \\
\hline Phatic-Repair & & 7 & & & 7 \\
\hline Phatic-Reaffirming & 8 & 64 & & & 72 \\
\hline
\end{tabular}




\begin{tabular}{|c|c|c|c|c|c|}
\hline Appeal-Reaffirming & & & 63 & 7 & 70 \\
\hline Appeal-Modal & & & 1 & & 1 \\
\hline Others & & 4 & 3 & & 7 \\
\hline TOTAL & 18 & 101 & 67 & 13 & 199 \\
\hline
\end{tabular}

\subsection{3 ¿iMira!?}

Data features 54 tokens of i imira!?. The analysis reveals that the tag is mainly used to draw the interlocutor's attention to a specific part of the utterance. i;Mira!? occurs in the initial, medial and final positions.

174. P1: aquí está // se lo llevan

175. P2: (( )) ¿te parece así?

176. P1: ¿imira!? aquí se lo llevan // las - las llegar // está dentro // está arrepentido [...] (1_BL_BOLIVIA)

'Here he is, they are taking him away'

'Do you think so?'

' $¡$ iMira!? here they are taking him ... he is inside (a prison), he is sorry'

89. P2: En la defensoría está / en la defensoría / el cuate arrepentido está ¿ ¡mira!?

90. P1: está / sigue con su chinela (5_BL_BOLIVIA)

'He is in the ombudsman office, in the ombudsman office, the guy is sorry iimira!?'

'He is ... he continues to wear his slippers'

252. P2: [...] AMBOS se recuerdan / me parece ¿ ¡mira!? luego / para eso yo había // ya // así // como se ya han formado antes una familia [...] (1_BL_BOLIVIA)

'BOTH remember, I think ¿jmira!? Then, for that I had, already, as well, they had already formed a family before'

When i imira!? occurs in both initial and medial positions, it mostly displays the phatic-focus function. The sender uses the tag as a tool to draw the listener's attention to a part of the utterance and, simultaneously, to make him/her pay attention to the upcoming words. In the final position, iimira!? appeals to the listener to collaborate with the sender by paying attention to those parts that the latter considers important to take into account. In summary, ijmira!? works as a cohesion marker that structures information by pointing out what the sender considers important. To appreciate the distribution of the tag with respect to its positions and pragmatic functions, see Table 4. 


\section{Ml Macrothink}

Table 4. The pragmatic functions of ¿imira!?

\begin{tabular}{|c|c|c|c|c|c|}
\hline & POSITI & & & & \\
\hline FUNCTION & Initial & Medial & Final & Isolated & TOTAL \\
\hline Phatic-Focus & 2 & 45 & & & 47 \\
\hline Appeal-Focus & & & 7 & & 7 \\
\hline TOTAL & 2 & 45 & 7 & & 54 \\
\hline
\end{tabular}

3.1.4 ¿Verdad?, ¿ya? and ¿entiendes?

In this section, I will discuss the three tags that occur less frequently in the data.

Through the label ¿verdad?, I will describe the functioning of two tag questions that behave as free variables, ¿verdad? (14 cases) and ¿es verdad? (3 cases). In the data, ¿verdad? occurs only in the final and medial positions. In the final position, it always displays the appeal-reaffirming function. The use of the tag in these contexts is due to the sender's will to obtain a confirmation from the interlocutor about what s/he has said (reaffirming function) and to involve him/her in the conversation.

114. P1: estaba aquí con la policía (3') este es la misma persona / ¿es verdad?

115. P2: sí // este era priormente (2_BL_BOLIVIA)

'He was here with the police. This is the same person ¿es verdad?'

'Yes, this was before'

When ¿verdad? occurs in the medial position, in one case it displays the agreement-informative function (see example 27). In the remaining cases, it has the phatic function. By using it, the sender wants either to reinforce his/her interpretation (28) or to structure his/her utterance (29).

14. P2: no para mí es (2',) es una figura

15. P1: figura /// ¿verdad? / ¿no? (2’’) yy - y la persona es muy alegre // sonriente // creo al ver l'imagen(1_BL_BOLIVIA)

'No, for me it is a figure'

'Figure ¿verdad? ¿no? And the person is very happy, smiling, I think if I look at the image'

250. P2: ¿se va aquí? /// se va aquí / ¿verdad? /// se va aquí(1_BL_BOLIVIA)

'Is he going here? He is going here / ¿verdad? He is going here'

271. P1: [...] yo / un día fui aa (3') al trabajo // en ese momento (3') yo no me había imaginado de que esto iba a tener / ¿verdad? yy / entonces de repente oi he pensado en que iba a estar un díaa FELIZ [...] (1_BL_BOLIVIA)

'Once, I went to work. At that time, I did not imagine that I would have this ¿verdad? And then, all of a sudden, I thought I was going to be HAPPY one day.' 
Concerning the last two tags present in the data, given the small number of occurrences, it was not possible to carry out an analysis. However, for the sake of completeness, I will show some examples.

194. P1: le voy a contar / le voy a contar (2') había - había - había una pareja ¿ya? una pareja / en esta pareja / el varón se llamaba Juan / ¿ya? / y pues la - la mujer / es decir / su mujer - su esposa se llamaba JUANA también [...] (1_BL_BOLIVIA)

'I am going to tell you, there was a couple $\measuredangle y a$ ? a couple, in this couple the man was called Juan $\measuredangle y a ?$ and then the woman, that is, his wife was called Juana as well.'

55. P1: [...] ha ido a su familia / ha ido a trabajar / aquí sucede la cosa ¿no ve? ¿entiendes? / ((esta)) parte no puedo ordenar [...] (4_BL_BOLIVIA)

'He went where his family lives / he went to work / the thing happens here ¿no ve? ¿entiendes? I cannot order this part'

In (30), the tag question $i y a$ ? is merely used with the phatic function, it keeps open the channel of communication. In (31) ¿entiendes? follows ¿no ve? and its use presupposes that the sender's arguments are not evident to the listener.

\subsection{Sociolinguistic Results}

The Bolivian Section of the Corpus Oral del español hablado por bilingüe de aymara-español (Quartararo, forth) consists of 39744 words, out of which 37494 were produced by participants and 2250 by interviewers. The absolute frequency of tag questions in the corpus corresponds to 498 tokens, that account for $1.3 \%$ of the total number of words pronounced by the participants.

When observing the distribution of tag questions according to the variable of gender, the analysis reveals that 247 cases $(48.6 \%)$ out of the total occurrences were uttered by women and 256 cases $(51.4 \%)$ by men. Out of the total number of words uttered by women (16 934), tag questions have a relative frequency of $1.4 \%$. On the other hand, out of the total number of words uttered by men (20 560), the 256 occurrences represent a relative frequency of $1.2 \%$. Women, therefore, utter more tag questions than men. However, by looking at the distribution of the analyzed tags by gender, these first results appear redistributed. Thus, women are who utter more ¿no ve?, ¿ya? and ¿entiendes?, while men record a higher relative frequency of ¿no? ¿jmira!? and ¿verdad?. The most relevant implication of this additional result is that the very high incidence of ¿no ve? in women's speech modifies the first result. Figure 1 shows in percentage terms the ratio between the absolute frequency of each tag question in each gender group and the total of words expressed by the same group. 


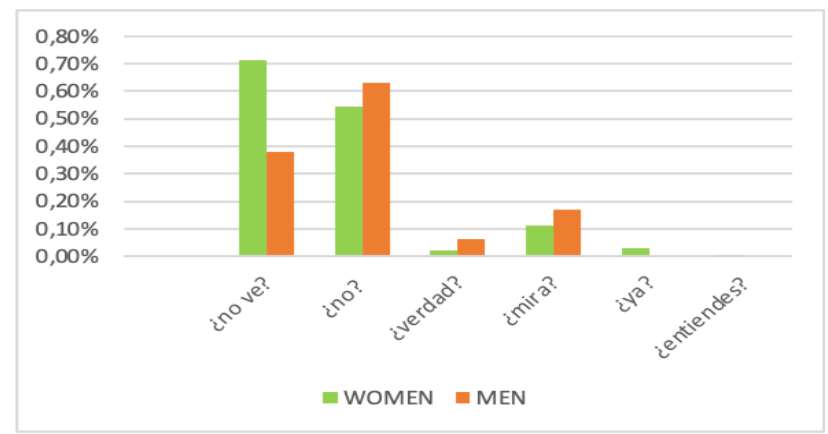

Figure 1. Distribution of tag questions according to the participants' gender

Concerning the frequency of tags in relation to the participants' age, the analysis shows that 286 cases $(57.4 \%)$ out of the total occurrences were uttered by young people, 159 cases $(31.9 \%)$ by adults, and finally, 53 cases $(10.6 \%)$ by elderly people. Out of the total number of words uttered by young people (20 719), tag questions record a relative frequency of $1.38 \%$. Out of the total number of words uttered by adults $(10473)$, they have a relative frequency of $1.52 \%$. Finally, out of the total number of words uttered by elderly participants (6 302), they account for a relative frequency of $0.84 \%$. The distribution among the three age groups of the six tag questions is shown in Figure 2.

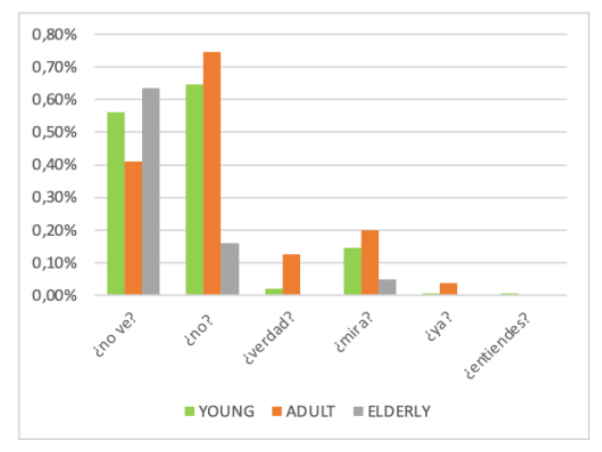

Figure 2. Distribution of detected tag questions according to the participants' age

Figure 2 shows that the variation of frequency among the three sociolinguistic groups is linked to specific tags. Thus, on the one hand, adults are the sociolinguistic group that proportionally uses the most ¿no?, ¿jmira!?, ¿verdad? and ¿ya?. On the other hand, elderly people are those that use ¿no ve? the most, despite being the group that in absolute terms records the least number of tag questions.

Finally, with regard to the participants' education, the sociolinguistic analysis shows that 402 cases $(80.7 \%)$ of the total occurrences were uttered by participants with university education, 44 cases $(8.8 \%)$ by participants with secondary education and, finally, 52 cases (10.5) by participants with primary education. Out of the total number of words uttered by participants with university education ( 25408 ), tag questions have a relative frequency of $1.6 \%$. Out of the total number of words uttered by participants with secondary education $(7247)$, they correspond to a frequency of $0.6 \%$. Finally, out of the total number of words uttered by elderly participants (4 839), they correspond to a frequency of $1.1 \%$. Figure 3 shows the distribution of the six tag questions among the three education groups. 


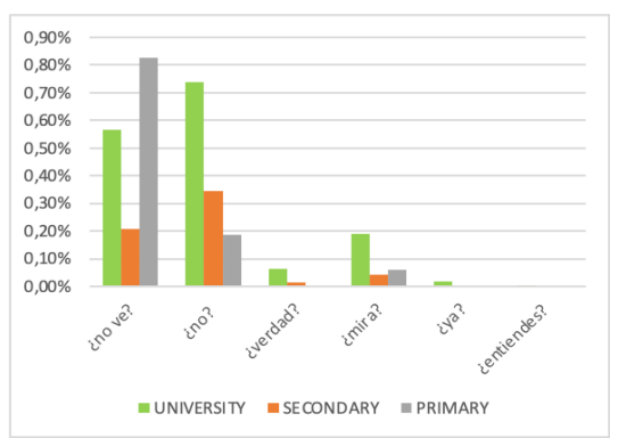

Figure 3. Distribution of tag questions according to the participants' education

Figure 3 highlights that the use of tag questions is most observed in the group with university education. The only exception to this trend is again related to ¿no ve? which, instead, registers a higher relative frequency in the group of participants with primary education.

\section{Discussion}

In line with the specialized literature, the qualitative analysis has shown that tag questions are multifunctional discursive units in two ways: (i) the same tag can perform different pragmatic functions depending on the discursive context where it occurs, and (ii) the same tag can convey multiple functions at the same time. The pragmatic value of a tag question, therefore, is strictly linked to the discursive context where it occurs and the configuration of the pragmatic functions that operate within it.

The analysis reveals that the absolute frequency of the six tag questions detected varies considerably. This first result allows to distinguish between frequent tags (¿no?, ¿no ve? and ¿imira!?) and occasional tags (¿verdad?, ¿ya? and ¿entiendes?). Furthermore, I noticed the quantitative preponderance of some functions over others. On the interactive plane, the preponderant function is the phatic one with a total of 280 cases. In descending order, this is followed by the appeal function (174 cases) and the agreement function (37 cases). On the modal plane, the reaffirming function is by far the most used, it records 287 occurrences which makes it the function with the highest absolute frequency. Finally, on the informative plane, I observed 82 cases of the focus function and 19 cases of the informative function. The relevant number of tags used with the reaffirming function however should not lead to any conclusions regarding the use of tag questions in the variety of Spanish under study. I consider that this number may strictly depend on the type of task used to elicit the data, that is, a task specifically designed to stimulate the interpretations of images in groups of two/three people (cf. §2.1).

The study also supports the Briz's claims by demonstrating the link between the position and the pragmatic functions of tags. Along these lines, the detected tag questions display the phatic function when they occur in the medial position and the appeal function when occurring in the final position. My results suggest an additional correlation, namely when tag questions are used according to the agreement function, they occur at the beginning of the sentence/turn or in the isolated position. Concerning the positions occupied by the analyzed tags, the study has shown a non-homogeneous distribution. Thus, ¿no ve? is the only tag that is observed in all four positions. ¿imira!? and ¿no? occur in the three positions bound to the host sentence. 
Finally, about the occasional tags, the reduced number of occurrences does not allow any conclusions to be drawn.

The results of the qualitative analysis (cf. §3.1) show a partial overlap among the functions performed by the tags. Table 5 brings together all pragmatic functions analyzed and shows that, on the one hand, the same function can be expressed through different tags. On the other hand, some functions are only conveyed through specific tags. In this regard, for instance, the agreement-informative and the phatic-reaffirming functions have been observed for ¿no?, ¿no ve? and ¿verdad?, while the agreement function is observed only for ¿no ve?

Table 5. The pragmatic functions of tag questions

\begin{tabular}{|c|c|c|c|c|}
\hline \multicolumn{5}{|c|}{ TAG QUESTIONS } \\
\hline FUNCTION & ¿No? & ¿No ve? & ¿Mira? & ¿Verdad? \\
\hline Agreement & & $\mathrm{X}$ & & \\
\hline Agreement-Focus & $X$ & $X$ & & \\
\hline Agreement-Informative & $X$ & $X$ & & $\mathrm{X}$ \\
\hline Phatic & $X$ & & & $\mathrm{X}$ \\
\hline Phatic-Focus & & $\mathrm{X}$ & $\mathrm{X}$ & \\
\hline Phatic-Repair & & $\mathrm{X}$ & & \\
\hline Phatic-Reaffirming & $X$ & $X$ & & $X$ \\
\hline Appeal-Reaffirming & $X$ & $X$ & & \\
\hline Appeal-Modal & $X$ & $\mathrm{X}$ & & \\
\hline Appeal-Focus & & & $X$ & \\
\hline Appeal & $X$ & $\mathrm{X}$ & & \\
\hline
\end{tabular}

Finally, the results of the sociolinguistic analysis led to some additional considerations. Firstly, the distribution of the tags analyzed by gender questions the Lakoff's (1973) claims according to whom women speech is characterized by a greater use of attenuation and tag questions. In the data, men utter more frequently the tags ¿no?, ¿verdad? and ¿imira!?, while women utter more frequently the tags ¿no ve? and ¿ya?. This result suggests a gender-dependent choice with respect to the tag to use, moreover, it opens the door to a series of new questions. Does this distribution correspond to a stable sociolinguistic pattern? Or is it exclusively tied to the variety of Spanish studied in this article? These questions remain open, and their answers have to be investigated in future research. Secondly, the analysis by age and education shows that tag questions are mostly uttered by adults with university education. The only exception to this trend is ¿no ve?. The tag, in fact, is more frequent in elderly people with primary education. This last result suggests that ¿no ve? is a tag used mainly by bilinguals with less linguistic competence in Spanish and greater in Aymara. If so, the tag could be a result of the influence of Aymara on Spanish. This last consideration is not intended to indicate the absence of the tag in other varieties of Spanish, but rather it emphasizes the need for further studies in this direction.

\section{Conclusions}

In summary, the present work has provided the first analysis of the use of tag questions in the variety of Andean Spanish spoken in Bolivia by Aymara-Spanish bilinguals. 


\section{Al Macrothink}

International Journal of Linguistics

ISSN 1948-5425

2021, Vol. 13, No. 3

The findings of this study, on the one hand, support the claims made in the literature. Here, the position of tags is related to their pragmatic functions (Briz, 2001; Montañez Mesa, 2008) and these discursive units are considered as multifunctional markers (Fuentes Rodríguez \& Brenes Peña, 2014). On the other hand, they question the claims made in the literature concerning women's speech (Lakoff 1973). In this regard, I have obtained comprehensive results that highlight the preferential relationship that exists between the choice of a specific tag and a specific sociolinguistic group.

Nevertheless, the present study has two main limitations. The first one lies in the partial homogeneity of the participants' sample. It is not very homogeneous with respect to the participants' age and education. This lack of homogeneity determines a consequent relevant difference in the participants' word production. I tried to tackle this limit by calculating the ratio between the absolute frequency of the tags in each sociolinguistic group and the total of words expressed by the same group. However, I do not exclude that such a limitation can have conditioned to some extent my results and, in this sense, investigations with larger and more homogeneous sample are needed. The second limitation concerns the lack of a third level of analysis that relates the functions of the identified tags with the participants' sociolinguistic characteristics. This lack is due to the limited length of the paper. Research into solving this limit is already in progress.

Research on the varieties of American Spanish need to continue conducting empirical studies in all fields of linguistic interest to ascertain the factors that characterized and distinguish all these varieties from each other, and from Peninsular Spanish. Specifically, in relation to the subject of this paper, I consider that empirical research should be conducted on tag questions in the unexplored varieties of American Spanish.

\section{References}

Adelaar, W., \& Muysken, P. (2004). The languages of the Andes, Cambridge language survey. Cambridge: Cambridge University Press. https://doi.org/10.1017/cbo9780511486852

Beinahuer, W. (1978). El español coloquial. Madrid: Gredos.

Blas Arroyo, J. L. (1995). La interjección como marcador discursivo: el caso de eh. Anuario de lingüística Hispánica, 6, 81-117.

Boretti, S. (1999). A propósito di ¿me entendés? En el español de la Argentina. Oralia, 2, 139-154.

Brenes Peña, E. (2011). Recursos lingüísticos al servicio de la (des) cortesía verbal: los apéndices apelativos. In C. Fuentes Rodriguez, E. Alcaide Lara, \& E. Brenes Peña (Eds.), Aproximaciones a la (des)cortesía verbal en español (pp. 155-184). Bern: Peter Lang.

Briz Gómez, A. (1998). El español coloquial en la conversación. Esbozo de pragmagramática. Barcelona: Ariel. 


\section{Macrothink}

International Journal of Linguistics

ISSN 1948-5425

2021, Vol. 13, No. 3

Briz Gómez, A. (2001). Acerca de la estructura conversacional del español coloquial. In F. Sánchez Miret (Ed.), Actas del XXIII Congreso Internacional de Lingüística y Filología Románica (pp. 147-156). https://doi.org/10.1515/9783110946260-015

Briz Gómez, A., \& Estellés Arguedas, M. (2010). On the relationship between attenuation, discourse particles and position. In G. Kaltenböck, W. Mihatsch, \& S. Schneider (Eds.), New approaches to hedging (pp. 289-304). Bingley: Emerald Group Publishing. https://doi.org/10.1163/9789004253247_014

Briz Gómez, A., \& Grupo Val, E. C. (2002). Corpus de conversaciones coloquiales. Madrid: Arco Libros.

Callisaya Apaza, G. (2012). El español de Bolivia. Contribución a la dialectología y a la lexicografía hispanoamericana. Doctoral Dissertation, Universidad de Salamanca.

Carranza, I. (1998). Conversación y deixis del discurso. Cordoba: Universidad Nacional de Cordoba.

Clancy Clements, J. (2009). The linguistic legacy of Spanish and Portuguese: Colonial expansion and language change. Cambridge: Cambridge University Press. https://doi.org/10.1017/cbo9780511576171

Coronel Molina, S., \& Rodríguez Mondoñedo, M. (2012). Introduction: Language contact in the Andes and Universal grammar. Lingua, 122, 447-460. https://doi.org/10.1016/j.lingua.2011.11.013

Cortés Rodríguez, L., \& Camacho Adarve, M. (2005). Unidades de segmentación y marcadores del discurso. Madrid: Arco/Libros.

Darnell, R., \& Labov, W. (1975). Sociolinguistic Patterns. Language, 51(4), 1008-1016. https://doi.org/10.2307/412715

Escobar, A. M. (2011). Spanish in contact with Quechua. In M. Díaz Campo (Ed.), The Handbook of Hispanic Sociolinguistics (pp. 65-88). Oxford: Wiley-Blackwell. https://doi.org/10.1002/9781444393446.ch16

Fuentes Rodríguez, C. (1990a). Apéndices con valor apelativo. Sociolingüística Andaluza, 5, 171-196.

Fuentes Rodríguez, C. (1990b). Procedimientos intradiscursivos: decir y los explicativos. Sociolingüística Andaluza, 5, 103-123.

Fuentes Rodríguez, C., \& Brenes Peña, E. (2014). Apéndices apelativos en el lenguaje parlamentario andaluz: variación pragmática. Oralia, 17, 181-209.

Fuentes Rodríguez, C., Placencia, M. E., \& Palma-Fahey, M. (2019). Operadores comprobativos y variación pragmática regional. RILI XVII, 1(33), 57-81.

García Vizcaíno, M. J. (2005). El uso de los apéndices modalizadores ¿no? y ¿eh? en español peninsular. In L. Sayahi, \& M. Westmoreland (Eds.), Selected Proceedings of the Second 
Workshop on Spanish Sociolinguistics, Cascadilla Proceedings Project (pp. 89-101). Somerville, MA: Cascadilla Proceedings Project.

Gille, J. (2013). Sobre el uso de los marcadores discursivos cachái, viste y te fijái al ini cio de turno. In N. G. Pardo, D. E. García da Silva, T. Oteiza, \& T. Asqueta (Eds.), Estudios del discurso en América Latina: Homenaje a Anamaría Harvey (pp. 465-484). Bogotá: Asociación Latinoamericana de Estudios del Discurso.

Gille, J. (2015). Los apéndices conversacionales en la argumentación: el caso de ¿cachái?. In G. Engwall, \& L. Fant (Eds.), Festival romanistica. Contribuciones lingüísticas (pp. 239-258). Stockholm: Stockholm University. https://doi.org/10.16993/bac.1

Lakoff, R. (1973). Language and woman's place. Language in Society, 2(1), 45-79.

Laprade, R. (1981). Some cases of Aymara influence on La Paz Spanish. In M. J. Hardman (Ed.), Aymara language in its social and cultural context (pp. 207-227). Gainesville (FL): University Presses of Florida.

Martín Zorraquino, M. A. (1998a). Estructura de la conversación y marcadores del discurso en español actual. In M. D. Muñoz Núñez, \& M. Casas Gómez (Eds.), IV Jornadas de Lingüística (pp. 223-265). Cádiz: Universidad de Cádiz.

Martín Zorraquino, M. A. (1998b). Los marcadores del discurso desde el punto de vista gramatical. In M. A. Martín Zorraquino, \& E. Montolío Durán (Eds.), Los marcadores del discurso, Teoría y análisis (pp. 19-54). Madrid: Arco Libros.

Mendoza, J. (1991). El castellano hablado en La Paz: sintaxis divergente. La Paz: Universidad Mayor de San Andrés.

Molina Martos, I. (2016). El apéndice interrogativo ¿sabes? y su doble difusión en la estructura social de la periferia madrileña (Valleca). Lingüística en la Red, 15, 1-17. https://doi.org/10.1163/9789004253247_014

Montañez Mesas, M. P. (2007). Marcadores del discurso y posición final: la forma ¿eh? en la conversación coloquial española. ELUA, 21, 1-20. https://doi.org/10.14198/ELUA2007.21.13

Montolío Durán, E. (2010). Estrategias de comunicación para mujeres directiva. Barcelona: Departament de Treball de la Generalitat de Catalunya y Fondo social Europeo.

Orozco, L. (2014). El empleo de ¿no?, ¿eh? y ¿verdad? en situación de entrevista sociolingüística. In P. M. Butragueño, \& L. Orozco (Eds.), Argumentos cuantitativos y cualitativos en sociolingüística: segundo coloquio de cambio y variación lingüística (pp. 628-654). México: Colegio de México. https://doi.org/10.2307/j.ctv6jmww1.27

Ortega Olivares, J. (1985). Apéndices modalizadores en español: los 'comprobativos'. Estudios Románicos Dedicados al Profesor Andrés Soria Ortega, 1, 239-255.

Ortega Olivares, J. (1986). Aproximación al mecanismo de la conversación: Apéndices ‘justificativos'. Verba, 13, 269-290. 


\section{Macrothink}

International Journal of Linguistics

ISSN 1948-5425

2021, Vol. 13, No. 3

Padilla García, X. (2005). Pragmática del orden de palabras. Alicante: Servicio de Publicaciones de la Universidad de Alicante.

Pyle, R. (1981). Bolivian Bilingual Spanish Phonology. In M. J. Hardman (Ed.), Aymara Language in its Social and Cultural Context (pp. 187-198.). Gainesville (FL): University Presses of Florida.

Quilis, A. (1993). Tratado de fonología y fonética españolas. Madrid: Gredos.

Rivadeneira Valenzuela, M. (2009). El voseo en medios de comunicación de Chile. Descripción y análisis de la variación dialectal y funcional. PhD dissertation. Barcelona: Universitat Pompeu Fabra.

San Martín, A. (2011). Los marcadores interrogativos de control de contacto en el corpus PRESEEA de Santiago de Chile. Boletín de Filología, 46(2), 135-166. https://doi.org/10.4067/s0718-93032011000200006

San Roque, L., Gawne, L., Hoenigman, D., Colleen Miller, J., Rumsey, A., Spronck, S., ... Evans, N. (2012). Getting the story straight: language fieldwork using a narrative problem-solving task. Language Documentation \& Conservation, 6, 135-174.

Urzúa Carmona, P. (2006). El verbo 'cachar' en el español coloquial de Chile. Onomázein, 13, 97-107.

\section{Notes}

Note 1. Translation: 'Reduced phonic elements, always emitted with rising or rising-falling intonation, that show the peculiarity of being associated with host sentences and occur at their end'.

Note 2. None of the participants spoke at the time of the recordings a further indigenous language; in the sample there are no cases of trilingual speakers. All participants were born as monolingual Aymara and learned Spanish during childhood.

Note 3. Orozco (2014) defines these cases of use of tag questions as 'reactive turn'.

\section{Copyrights}

Copyright for this article is retained by the author(s), with first publication rights granted to the journal.

This is an open-access article distributed under the terms and conditions of the Creative Commons Attribution license (http://creativecommons.org/licenses/by/4.0/) 